\title{
Gamification Wisata di Museum Mpu Tantular Berbasis Augmented Reality
}

\author{
Faiz Fathur Rahman, Surya Sumpeno dan Ahmad Zaini \\ Departmen Teknik Komputer, Fakultas Teknologi Elektro, Institut Teknologi Sepuluh Nopember \\ E-mail : faiz.fathur13@mhs.te.its.ac.id, surya@te.its.ac.id, zaini@te.its.ac.id
}

\begin{abstract}
Abstrak-Museum sebagai sumber informasi peradaban dan kebudayaan telah menyajikan informasi terkait koleksi benda museum. Namun penyajian informasi yang tersedia cenderung diabaikan karena kurangnya minat pengunjung untuk mengetahui informasi terkait koleksi benda museum. Akibatnya adalah pengetahuan pengunjung terkait koleksi Museum Mpu Tantular tidak bertambah. Pada studi ini dibangun suatu media yang dapat berinteraksi dua arah sehingga informasi tersebut dapat tersampaikan dengan baik dan penyajian informasi terkait koleksi Museum Mpu Tantular lebih menarik dan interaktif. Hasil yang diperoleh adalah aplikasi permainan tour museum dengan memanfaatkan penerapan teknologi augmented reality pada gamification sehingga pengunjung terpacu untuk men-cari informasi terkait koleksi Museum Mpu Tantular. Setelah melakukan pengujian didapatkan hasil survei dari seluruh responden yang menyatakan bahwa aplikasi permainan tour museum dapat menambah pengetahuan terkait koleksi Museum Mpu Tantular. Dibuktikan oleh rata-rata jawaban benar yang mengalami kenaikan sebesar $27,87 \%$ dari sebelum dan sesudah mencoba aplikasi ini.
\end{abstract}

Keywords-Gamification, Museum, Augmented Reality.

\section{PENDAHULUAN}

$\mathrm{M}$ USEUM adalah lembaga, tempat penyimpanan, perawatan, pengamanan dan pemanfaatan benda-benda bukti materiil hasil budaya manusia serta alam dan lingkungannya guna menunjang upaya perlindungan dan pelestar-ian kekayaan budaya bangsa [1]. Pemanfaatan yang dimak-sud difungsikan untuk menyajikan kepada masyarakat sebagai sumber informasi, sarana pendidikan, dan rekreasi. Mu-seum sebagai sumber informasi peradaban dan kebudayaan telah menyajikan informasi terkait koleksi benda museum sehingga memiliki daya tarik kepada masyarakat untuk berkunjung ke museum sebagai sarana pembelajaran dan rekreasi. Sarana pembelajaran dan rekreasi yang dapat dilakukan oleh masyarakat dengan menggunakan gamification.

Gamification menurut Bunchball, Inc (2010) adalah menerapkan mekanisme permainan untuk kegiatan non-game untuk mengubah perilaku masyarakat [2]. Gamification berkerja den-gan membuat teknologi dengan mendorong pengguna untuk terlibat dalam perilaku yang diinginkan [3]. Gamification yang diterapkan untuk meningkatkan daya tarik masyarakat yaitu permainan tour museum. Masyarakat dituntut menjelajah di area museum untuk mencari informasi terkait koleksi benda museum. Gamification cenderung mengajak pengguna untuk tidak hanya sekedar mengetahui sebuah informasi atau belajar, namun juga dapat bermain agar terdapat sebuah interaksi [3] Interaksi yang digunakan dalam penggunaan gamification menggunakan teknologi augmentend reality (AR).

Teknologi AR merupakan teknik penggabungan citra antara dunia maya dengan dunia nyata [4]. Dengan menggunakan teknologi AR, masyarakat dapat berinteraksi dengan informasi koleksi benda museum sehingga ada keinginan untuk menge-tahui lebih jauh terkait informasi yang telah disediakan oleh museum. Apabila teknologi AR dapat diterapkan pada gami-fication maka akan menjadi sarana pembelajaran interaktif di area museum.

\section{DESAIN SISTEM}

Penelitian ini bertujuan untuk membangun sebuah aplikasi permainan tour museum dengan memanfaatkan penerapan teknologi augmented reality pada gamification sehingga pengunjung terpacu untuk mencari informasi terkait koleksi $\mathrm{Mu}$ seum Mpu Tanturlar. Informasi ditampilkan secara interaktif melalui teknologi AR sehingga pengunjung mendapatkan informasi terkait koleksi Museum Mpu Tanturlar. Secara tidak sadar pengetahuan terkait koleksi Museum Mpu Tanturlar akan bertambah. Gamification yang diterapkan dalam aplikasi permainan adalah permainan Treasure Hunt Museum Mpu Tantular.

Pembangunan sistem pada penelitian ini memiliki tiga tahap utama dalam merancang dan mengimplementasikan desain sistem aplikasi sehingga dapat digunakan sebagai luaran akhir seperti pada gambar 1. Tiga tahap utama alur perancangan sebagai berikut:

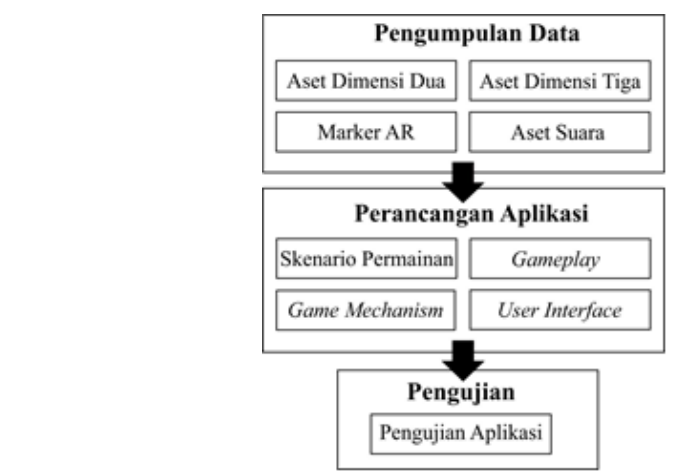

Gambar 1. Alur perancangan

1) Pengumpulan Data

Pengumpulan data merupakan tahap mempersiapkan aset yang akan digunakan pada aplikasi. Aset yang 
perlu disiapkan adalah aset dimensi dua, aset dimensi tiga, dan marker AR.

2) Perancangan Aplikasi

Dalam perancangan aplikasi ini membutuhkan skenario permainan berupa target pemain, alur cerita dan karakter yang digunakan. Gameplay berupa kontrol permainan dan kondisi menang atau kalah. Game mechanism berupa metode Gamification, Finite State Machines (FSM) dan Storyboard. User interface yang terdapat pada Treasure Hunt Museum Mpu Tantular berfungsi untuk menjalankan Game mechanism antara pengguna dan sistem serta melihat objek dimensi tiga.

3) Pengujian

Pada tahap ini bertujuan untuk menguji kelayakan dan kesesuaian fungsi-fungsi yang telah ditanamkan pada aplikasi sehingga dapat digunakan dikawasan museum.

Aplikasi ini digunakan pada perangkat mobile dengan sis tem operasi Android. Perancangan aplikasi ini menggunakan libary Vuforia dan perangkat lunak Unity 3D. Libary Vufo-ria mengerjakan proses gambar dari marker untuk dijadikan augmented reality sehingga dapat menampilkan objek virtual. Objek virtual yang akan ditampilkan harus diproses terlebih dahulu di Unity 3D. Setelah itu Unity 3D juga menangani pembuatan user inter face pada aplikasi ini. Dengan begitu Unity 3D memiliki peran sebagai editor.

1) Aset

Aset gambar dimensi dua yang ditampilkan pada aplikasi ini merupakan objek dimensi dua. Aset gambar tersebut meliputi icon button, karakter, peta, objek di-mensi dua, dan background seperti pada gambar. Hasil aset gambar dari perangkat lunak tersebut berupa file (.png atau .jpg). Contoh aset gambar dapat dilihat pada gambar 2 .
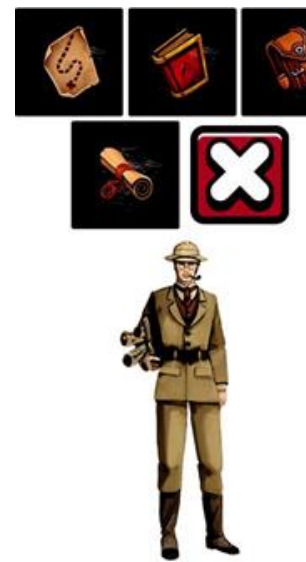

Gambar 2. Aset dimensi dua

Objek virtual yang ditampilkan pada permainan Treasure Hunt Museum Mpu Tantular merupakan objek dimens i tiga berupa beberapa koleksi arca perunggu di Musuem Mpu Tantular. Terdapat tiga objek utama di-mensi tiga yang ditampilkan pada objek virtual. Contoh objek dimensi seperti pada gambar 3 .

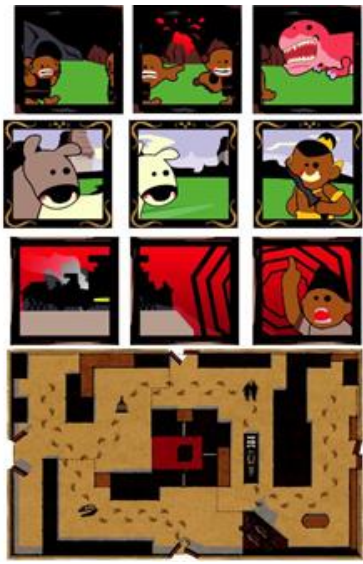

Gambar 3. Aset dimensi 3

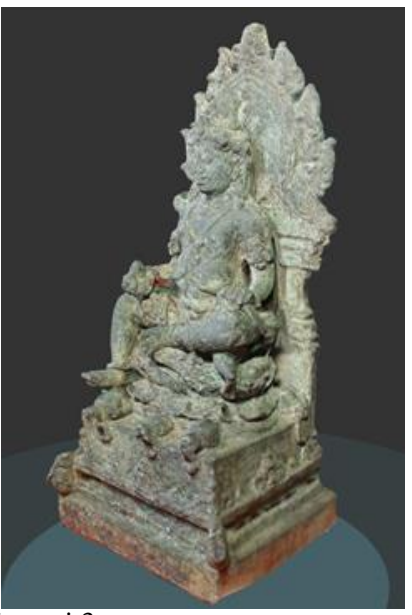

2) Marker

Marker augmented reality dipergunakan sebagai sarana berinteraksi pengguna dengan informasi terkait koleksi benda museum. Nantinya objek virtual dalam bentuk objek dimensi dua divisualisasikan pada layar perangkat melalui citra marker augmented reality pada aplikasi ini. Pembuatan citra dimensi dua sebagai marker augmented reality menggunakan fitur online target man-ager. Fitur target manager terdapat di website resmi Vuforia. Didalam website tersebut terdapat alur proses yang bertugas sebagai penentuan fitur marker seperti pada gambar 4. Dengan begitu aplikasi yang telah terintegrasi dengan library Vuforia SDK dapat mendeteksi dan melacak posisi citra marker tersebut.

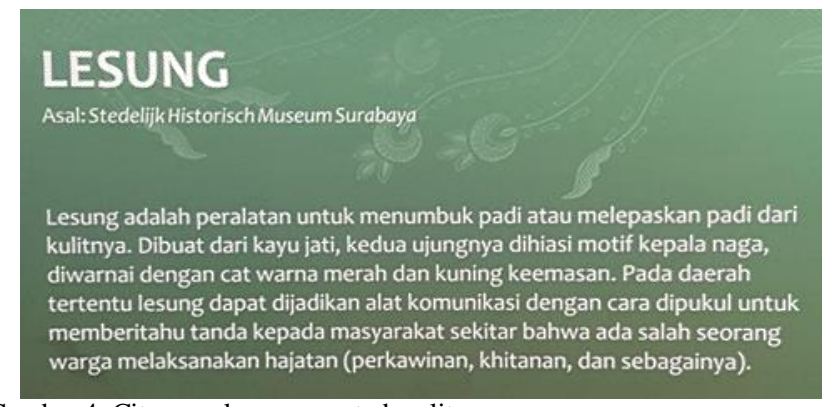

Gambar 4. Citra marker augmented reality

\section{PERANCANGAN APLIKASI}

Perancangan aplikasi dibutuhkan untuk mendesain rancangan aplikasi agar dapat diimplementasikan dengan tepat. Perancangan pada aplikasi ini di desain melalui skenario permainan, gameplay, game mechanism, dan user interface.

\section{1) Skenario Permainan}

Treasure Hunt Museum Mpu Tantular merupakan permainan pencarian kunci peti harta karun berlokasi dikawasan Museum Mpu Tantular. Permainan ini bertipe petualangan dimana untuk mendapatan kunci peti harta karun menggunakan petunjuk yang telah diberikan. Ske-nario permainan pada Treasure Hunt Museum Mpu Tantular memiliki alur cerita sehingga memiliki benang merah atau inti dari cerita dalam permainan ini. 
Alur Cerita

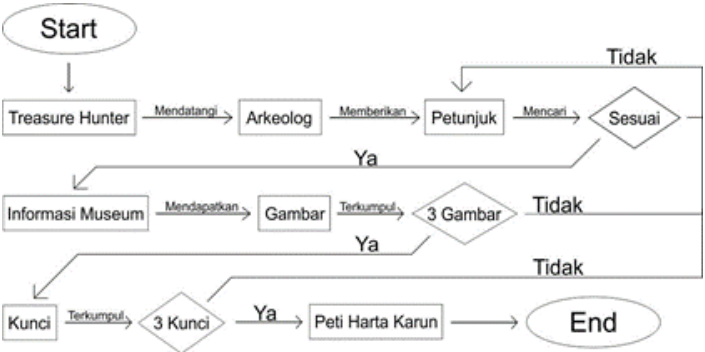

Gambar 5. Alur cerita pada permainan

Pada gambar 5 merupakan alur cerita pada per-mainan Treasure Hunt Museum Mpu Tantular.

\section{2) Gameplay}

Peti harta karun memiliki tiga lubang sehingga dibu-tuhkan tiga kunci untuk membuka peti harta karun. Satu kunci peti harta karun hanya untuk satu periodesasi. Satu kunci peti harta karun tersebut dapat ditemukan dengan cara mendapatkan tiga gambar. Setiap gambar memiliki masingmasing petunjuk. Petunjuk tersebut diperoleh dari pemberian Arkeolog dan berupa potongan-potongan teks informasi dari objek museum. Kemudian untuk mendapatkan gambar tersebut dari petunjuk yang telah diberikan. Apabila petunjuk dan teks informasi dari objek museum sesuai maka salah satu dari ketiga gambar tersebut berada diposisi tersebut. Satu gambar didapatkan dengan cara mencari marker. Ketika marker terdeteksi maka satu gambar tersebut akan mucul. Kemudian Treasure Hunter da-pat mencari gambar lain dari petunjuk yang telah diberikan oleh Arkeolog. Apabila ke tiga gambar terse-but terkumpul maka satu buah kunci peti harta karun tersebut akan muncul.

Sebelum munculnya kunci peti harta karun akan ada mini game. Setelah memainkan permainan mini game tersebut maka dapat melihat kunci peti harta karun. Kunci peti harta karun tersebut adalah objek dimensi tiga yang telah direkontruksi. Treasure Hunter dapat mencari kunci peti harta karun lain dari petunjuk yang telah diberikan oleh Arkeolog. Jadi terdapat tiga mini game untuk mendapat tiap-tiap kunci peti harta karun. Apabila ketiga kunci peti harta karun telah terkumpul maka peti harta karun dapat dibuka.

\section{3) Game Mechanism}

Game mechanism adalah gabungan dari berba-gai macam aturan untuk interaksi dengan permainan sehingga membentuk sebuah gameplay. Aturan-aturan tersebut menjelaskan tentang cara memainkan per-mainan Treasure Hunt Museum Mpu Tantular. Aturan-aturan yang terdapat dalam permainanTreasure Hunt Museum Mpu Tantular berupa mendapatkan points, mendapatkan levels, mendapatkan challenges dan lain-lain.

4) Gamification

Pada permainan Treasure Hunt Museum Mpu Tan-tular menerapkan suatu bidang keilmuan yang kini dike-nal dengan istilah gamification. Pada tabel I terdapat enam elemen yang terdapat dari mekanik permainan dan enam keinginan manusia dari sebuah permainan. Dalam permainan Treasure
Hunt Museum Mpu Tantular menggunakan tiga elemen dari mekanik permainan dan tiga keinginan manusia dari sebuah permainan, sebagai berikut:

Tabel 1.

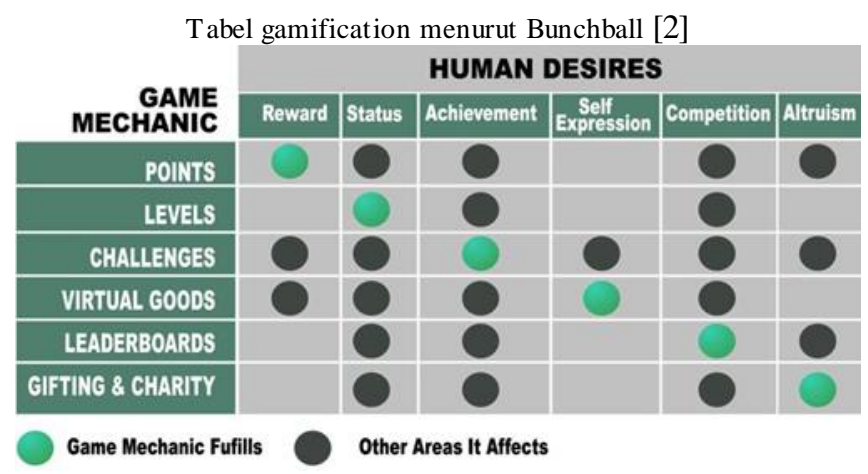

a) Points

Pada tabel I, points berkaitan dengan reward yang akan didapat ketika permainan telah berakhir. Points didapatkan dari menemukan masing-masing gambar, memainkan permainan dari mini game disetiap level dan muncul ketiga kunci peti harta karun tersebut. Apabila telah membuka peti harta karun, Treasure Hunter akan mendapatkan reward bahwa telah menyelesaikan pencarian kunci peti harta karun.

b) Reward

Reward didapat dari skor yang telah diperoleh Treasure Hunter. Reward yang didapat dalam per-mainan Treasure Hunt Museum Mpu Tantular adalah cendramata atau souvenir dari museum Mpu Tantular.

c) Levels

Levels berkaitan dengan status sehingga Trea-sure Hunter akan tahu sudah sejauh manakah memainkan sebuah permainan. Dalam permainan Treasure Hunt Museum Mpu Tantular memiliki tiga levels. Levels yang digunakan adalah zona dalam gedung pameran Museum Mpu Tantular. Tiga zona tersebut yaitu:

i) Zona Pra Sejarah.

ii) Zona Klasik.

iii) Zona Kolonial dan Kemerdekaan.

d) Status

Status dalam permainan Treasure Hunt Museum Mpu Tantular sebagai tahapan Treasure Hunter sejauh mana memainkan permain ini.

e) Challenges

Challenges berkaitan dengan achievement yang akan didapat oleh pemain. Ketika telah selesai memainkan mini game akan mendapatkan sebuah achievement. Ada beberapa jenis achievement yang didapatkan dan akan dibahas selanjutnya.

f) Achievment

Ketika Treasure Hunter memainkan permainan Treasure Hunt Museum Mpu Tantular akan men-dapatkan sebuah achievement, yaitu:

i) Mendapatkan skor sempurna dalam memainkan permainan Treasure Hunt Museum Mpu Tantu-lar. 
ii) Mendapatkan skor sempurna dalam mini game menyusun puzzle.

iii) Mendapatkan skor sempurna dalam mini game merakit symphonion.

iv) Mendapatkan skor sempurna dalam mini game mencari benda.

g) Storyboard

Storyboard adalah visualisasi ide dari aplikasi yang akan dibangun sehingga dapat memberikan gambaran dari aplikas i yang akan dihasilkan. Nantinya outline tersebut akan ditampilkan shot by shot yang disebut dengan istilah scene. Dalam permainan Treasure Hunt Museum Mpu Tantular terdapat storyboard untuk mem-berikan gambar dari aplikasi permainan ini. Storyboard permainan Treasure Hunt Museum Mpu Tantular seperti pada gambar 6.

\section{4) User Interface (UI)}

Dalam permainan Treasure Hunt Museum Mpu Tantular terdapat user interface untuk dapat berkomu niasi antara pengguna dengan sistem permainan. User interface pada permainan Treasure Hunt Museum Mpu Tantular terbagi ke dalam lima scene utama yaitu scene main menu, scene menu game AR, scene mini game menyusun puzzle, scene mini game merakit symphonion, dan scene mini game mencari benda.

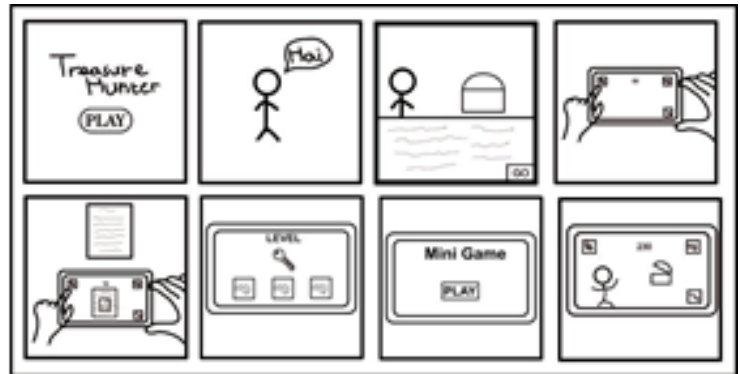

Gambar 6. Storyboard pada permaianan Treasure Hunt Museum Mpu Tantular

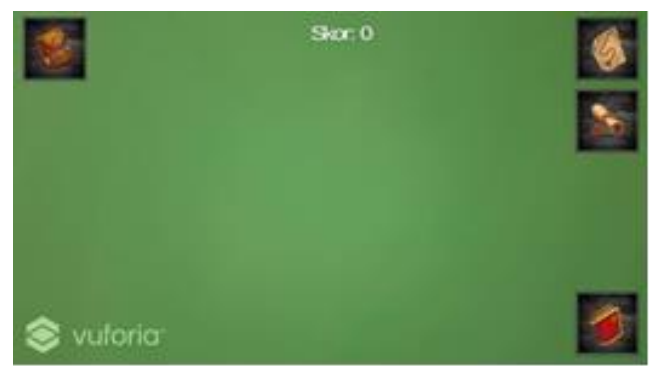

Gambar 7. Tampilan user interface pada scene menu game AR

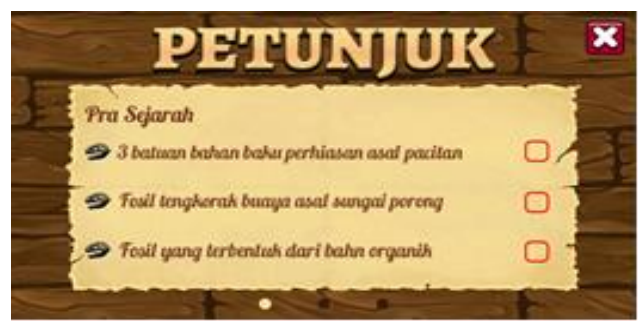

Gambar 8. Tampilan user interface petunjuk pada permainan ketika belum mendapatkan sembilan gambar

\section{PENGUJIAN}

Pengujian pada penelitian ini dilakukan untuk menge-tahui pengalaman yang dialami pengguna saat berinteraksi dengan alat digital dan untuk mengukur pengetahuan peng-guna terkait informasi koleksi benda Museum Mpu Tantular. Dalam mengetahui pengalaman yang dialami pengguna saat berinteraksi dengan alat digital menggunakan metode User Experience (UX). Desain metode User Experience seperti pada gambar 9 .

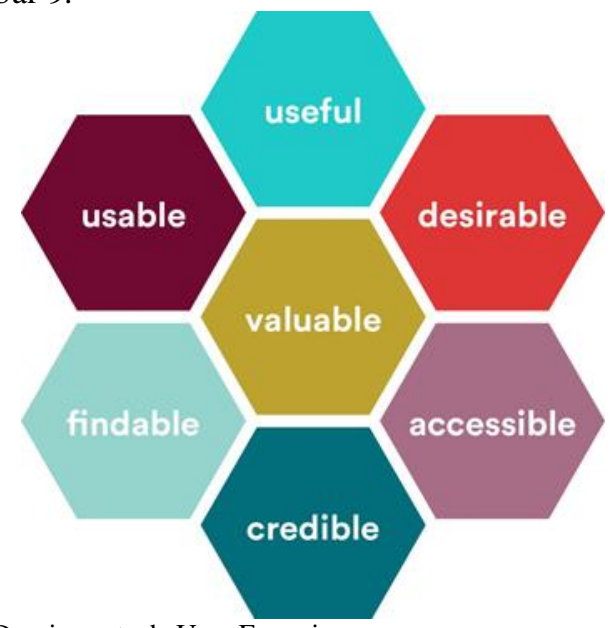

Gambar 9. Desain metode User Experience

Tabel 2.

Hasil pengujian Untuk mengetahui pengalaman yang dialami pengguna saat berinteraksi dengan alat digital

\begin{tabular}{r|r|r|r|r|r|}
\hline \multirow{2}{*}{ No } & \multirow{2}{*}{ Pernyataan } & \multicolumn{4}{|c|}{ Jawaban } \\
\cline { 3 - 6 } & & SS & \multicolumn{1}{c|}{ S } & TS & ST S \\
\hline 1 & Pernyataan 1 & $23,33 \%$ & $76,67 \%$ & $0 \%$ & $0 \%$ \\
\hline 2 & Pernyataan 2 & $33,33 \%$ & $63,33 \%$ & $3,33 \%$ & $0 \%$ \\
\hline 3 & Pernyataan 3 & $46,67 \%$ & $53,33 \%$ & $0 \%$ & $0 \%$ \\
\hline 4 & Pernyataan 4 & $70 \%$ & $30 \%$ & $0 \%$ & $0 \%$ \\
\hline 5 & Pernyataan 5 & $26,33 \%$ & $70 \%$ & $3,33 \%$ & $0 \%$ \\
\hline 6 & Pernyataan 6 & $43,33 \%$ & $53,33 \%$ & $3,33 \%$ & $0 \%$ \\
\hline 7 & Pernyataan 7 & $53,33 \%$ & $40 \%$ & $6,67 \%$ & $0 \%$ \\
\hline 8 & Pernyataan 8 & $46,67 \%$ & $46,67 \%$ & $6,67 \%$ & $0 \%$ \\
\hline 9 & Pernyataan 9 & $63,33 \%$ & $36,67 \%$ & $0 \%$ & $0 \%$ \\
\hline 10 & Pernyataan 10 & $46,67 \%$ & $46,67 \%$ & $6,67 \%$ & $0 \%$ \\
\hline 11 & Pernyataan 11 & $30 \%$ & $66,67 \%$ & $3,33 \%$ & $0 \%$ \\
\hline 12 & Pernyataan 12 & $23,33 \%$ & $76,67 \%$ & $0 \%$ & $0 \%$ \\
\hline 13 & Pernyataan 13 & $16,67 \%$ & $63,33 \%$ & $16,67 \%$ & $3,33 \%$ \\
\hline 14 & Pernyataan 14 & $33,33 \%$ & $63,33 \%$ & $3,33 \%$ & $0 \%$ \\
\hline 15 & Pernyataan 15 & $13,33 \%$ & $80 \%$ & $6,67 \%$ & $0 \%$ \\
\hline 16 & Pernyataan 16 & $3,33 \%$ & $83,33 \%$ & $13,33 \%$ & $0 \%$ \\
\hline 17 & Pernyataan 17 & $20 \%$ & $76,67 \%$ & $3,33 \%$ & $0 \%$ \\
\hline
\end{tabular}

Terdapat enam elemen pada User Experience, sebagai berikut: 1) Useful berkaitan dengan konten yang tersedia adalah asli dan memenuhi kebutuhan.

2) Usable berkaitan dengan kemudahan menggunakan suatu produk secara efektif dan efisien.

3) Desirable berkaitan dengan desain suatu produk memalui merek, gambar, identitas, dan estetika sehingga digunakan untuk membangkitkan desain emosi peng-guna.

4) Findable berkaitan dengan kemudahan dalam mencari informasi di suatu produk.

5) Accessible berkaitan dengan kemudahan mengakses suatu produk termasuk orang-orang yang memiliki disabil-itas. Credible berkaitan dengan kepercayaan pengguna ter-hadapat suatu produk 
Untuk mengukur pengetahuan pengguna terkait infor-masi koleksi benda Museum Mpu Tantular dibutuhkan re-sponden. Responden dalam penelitian ini yaitu pengunjung Museum $\mathrm{Mpu}$ Tantular. Jumlah responden dalam pengujian ini sebanyak 30 responden. Survei dilakukan oleh responden ketika sebelum dan sesudah mencoba aplikasi.

\section{PENGUJIAN APLIKASI}

Untuk mengetahui pengalaman yang dialami pengguna saat berinteraksi dengan alat digital menggunakan metode kuisioner User Experience (UX). Didapatkan dari 30 orang responden yang merupakan pengunjung Museum Mpu Tantular pada tabel II.

Pada pernyataan peryataan nomor satu sampai empat yang ditunjukan untuk elemen useful terdapat 52 jawaban atau $43,33 \%$ responden sangat setuju, 67 jawaban atau 55,83\% responden setuju dan satu jawaban atau $0.83 \%$ respondem tidak setuju. Pada peryataan nomor lima sampai tujuh yang ditunjukan untuk elemen usable terdapat 37 jawaban atau $41,11 \%$ responden sangat setuju, 49 jawaban atau 54,44\% responden setuju dan empat jawaban atau $4.44 \%$ responden tidak setuju.

Pada pernyataan peryataan nomor delapan sampai 10 yang ditunjukan untuk elemen desirable terdapat 47 jawaban atau $52,22 \%$ responden sangat setuju, 39 jawaban atau $43,33 \%$ responden setuju dan empat jawaban atau $4,44 \%$ responden tidak setuju. Pada peryataan nomor 11 sampai 14 yang ditunjukan untuk elemen findable terdapat 31 jawaban atau $41,11 \%$ responden sangat setuju, 81 jawaban atau $54,44 \%$ responden setuju, tujuh jawaban atau $4.44 \%$ responden tidak setuju dan satu jawaban atau $4.44 \%$ reponden sangat tidak setuju.

Pada pernyataan peryataan nomor 15 dan 16 yang ditunjukan untuk elemen accessible terdapat lima jawaban atau $8,33 \%$ responden sangat setuju, 49 jawaban atau $81,67 \%$ responden setuju dan enam jawaban atau $10 \%$ responden tidak setuju. Pada peryataan nomor 17 yang ditunjukan untuk elemen credible terdapat enam jawaban atau $20 \%$ responden sangat setuju, 23 jawaban atau 26,67\% responden setuju dan satu jawaban atau $3,33 \%$ responden tidak setuju.

\section{PENGUJIAN WAWASAN PENGGUNA}

Untuk mengukur pengetahuan pengguna terkait infor-masi koleksi benda Museum Mpu Tantular diberikan soal pre-test dan post-test. Berikut adalah gambar grafik 10, 11, 12, 13, dan 14 merupakan grafik kenaikan jawaban benar yang ditunjukkan masing-masing responden:

Dari lima gambar grafik 10, 11, 12, 13, dan 14 yang dihasilkan dari masing-masing responden diperoleh rata-rata kenaikan jawaban benar sebesar tiga jawaban benar atau $27,87 \%$.

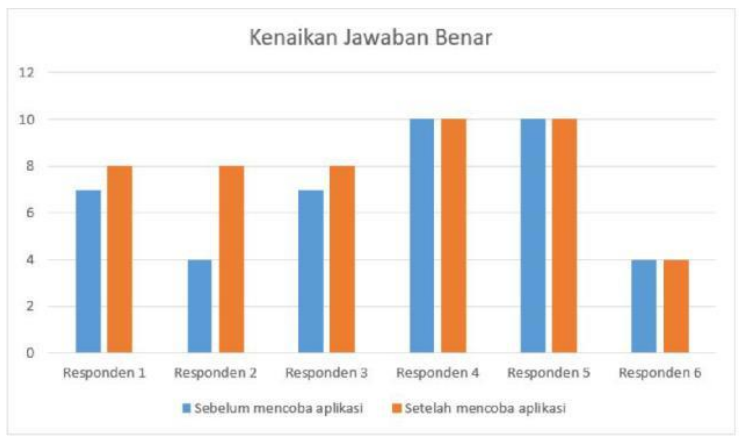

Gambar 10. Grafik responden satu sampai enam

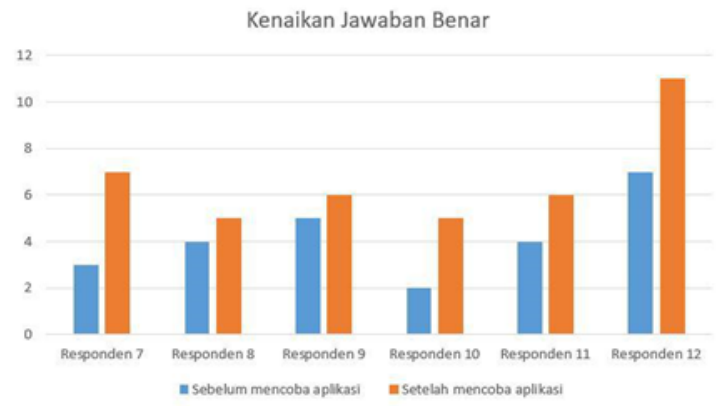

Gambar 11. Grafik responden tujuh sampai 12

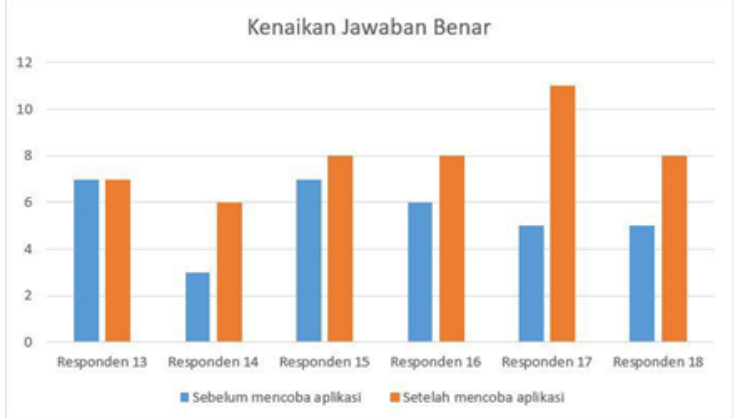

Gambar 12. Grafik responden 13 sampai 18

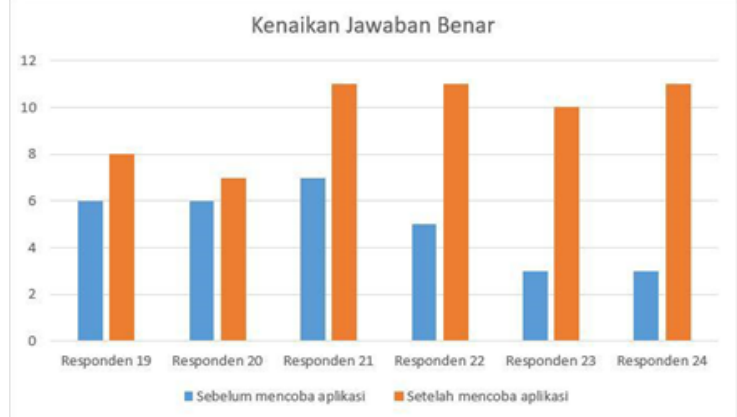

Gambar 13. Grafik responden 19 sampai 24

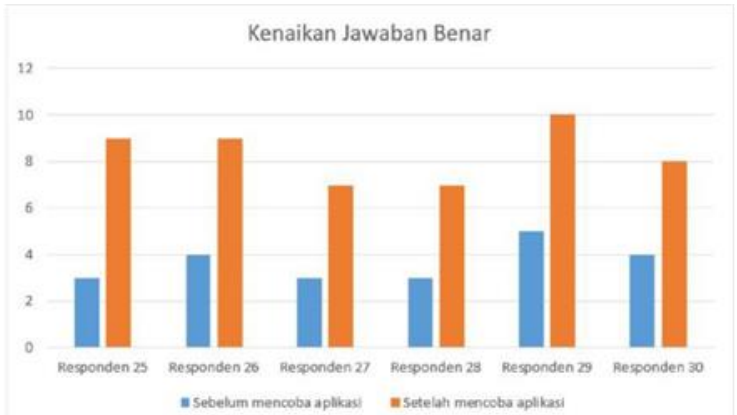

Gambar 14. Grafik responden 25 sampai 30 


\section{KESIMPULAN}

Pada penelitian ini telah dijelaskan pembuatan aplikasi permainan tour museum dengan memanfaatkan penerapan teknologi augmented reality pada gamification. Dari hasil pengujian yang telah dilakukan di Museum Mpu Tantular dapat ditarik beberapa kesimpulan, yaitu:

1. Hal ini menunjukan bahwa pengalaman yang dialami pengguna saat berinteraksi dengan alat digital sudah baik. Dibuktikan dengan tingkat penerimaan terhadap User Experience yang ditunjukan Useful, Usable, Desir-able, Findable, Accessible dan Credible, sebagai berikut:

a) Sebanyak 55,83\% responden setuju bahwa aplikasi permainan ini memenuhi elemen Useful.

b) Sebanyak $54,44 \%$ responden setuju bahwa aplikasi permainan ini memenuhi elemen Usable.

c) Sebanyak $52,22 \%$ responden sangat setuju bahwa aplikasi permainan ini memenuhi elemen Desir-able.

d) Sebanyak $67,5 \%$ responden setuju bahwa aplikasi permainan ini memenuhi elemen Findable.

e) Sebanyak $81.67 \%$ responden setuju bahwa aplikasi permainan ini memenuhi elemen Accessible. f) Sebanyak $76,67 \%$ responden setuju bahwa aplikasi permainan ini memenuhi elemen Credible.

2. Kelayakan aplikasi sebagai media pembelajaran di museum terpenuhi karena pengetahuan seluruh responden terkait informasi koleksi Museum Mpu Tantular bertambah. Dibuktikan dengan diperolehnya rata-rata kenaikan jawaban benar sebesar tiga jawaban benar atau $27,87 \%$ untuk masing-masing responden ketika sebelum dan sesudah mencoba aplikasi.

\section{DAFTAR PUSTAKA}

[1] R. Indonesia, Pemiliharaan dan Pemanfaatan Benda Cagar Budaya di Museum. Jakarta, 1995.

[2] B. Inc, Gamification 101: An Introduction to the Use of Game Dynamics to Influence Behavior. Bunchball white paper, 2010.

[3] and M. I. J. J. Lee, T. College, D. Ph, E. Hammer, "Gamification in Education : What, How, Why Bother? What : Definitions and Uses," vol. 15, pp. 1-5, 2011.

[4] V. Geroimenko, "Augmented reality technology and art: The analysis and visualization of evolving conceptual models," in Proceedings of the International Conference on Information Visualisation, 2012, pp. 445-453. 